\title{
PENGARUH CORPORATE SOCIAL RESPONSIBILITY (CSR), KEPEMILIKAN INSTITUSIONAL, KEPEMILIKAN MANAJERIAL, PROFITABILITAS DAN STRUKTUR MODAL TERHADAP NILAI PERUSAHAAN
}

\author{
Budi Tri Santoso \\ Fakultas Ekonomi, Universitas Pamulang \\ Email: dosen01988@unpam.ac.id
}

\begin{abstract}
Purpose. This study aims to determine whether Corporate Social Responsibility (CSR), Institutional Ownership, Managerial Ownership, Profitability, and Capital Structure have a simultaneous and partial effect on firm value.
\end{abstract}

Methods. The method of data collection is done by inferential statistical method (Parametric). The sample companies used in this study were 8 manufacturing companies in the consumer goods industry sector listed on the Indonesia Stock Exchange. The data used are secondary data from financial reports and annual reports for the period 2011-2015. The data collected were analyzed by correlation and multiple linear regression as well as hypothesis testing which was carried out using the statistical program application, SPSS 20.0.

Findings. The results showed that the study was free from classical assumptions, namely data with normal distribution, and free from multicollinearity, autocorrelation, and heteroscedasticity. Partially (alone) shows that there is a significant influence between Corporate Social Responsibility (CSR) on firm value, there is no significant effect between Institutional Ownership on firm value, there is no significant effect between Managerial Ownership on firm value, profitability significant effect on firm value, and there is a significant effect between capital structure on firm value. Simultaneously there is a significant influence between Corporate Social Responsibility (CSR), Institutional Ownership, Managerial Ownership, Profitability, and Capital Structure in Consumer Goods Manufacturing companies.

Implication. Further research can also add research data by adding company sectors to other industries other than Manufacturing Companies in the Consumer Goods Industry Sector so that this research is expected to provide generalizable results for all companies in Indonesia.

Keywords. Corporate Social Responsibility (CSR), Institutional Ownership, Managerial Ownership, Profitability, Capital Structure, Company Value.

\begin{abstract}
ABSTRAK
Tujuan. Penelitian ini bertujuan untuk mengetahui apakah Corporate Social Responsibility (CSR), Kepemilikan Institusional, Kepemilikan Manajerial, Profitabilitas, dan Struktur Modal berpengaruh secara serentak dan parsial terhadap Nilai Perusahaan.

Metode. Metode pengumpulan data dilakukan dengan metode statistik inferensial (Parametrik). Sampel perusahaan yang digunakan dalam penelitian ini adalah 8
\end{abstract}


perusahaan Manufaktur Sektor Industri Barang Konsumsi Yang Terdaftar di Bursa Efek Indonesia. Data yang digunakan adalah data sekunder dari laoran keuangan dan laporan tahunan periode tahun 2011-2015. Data yang terkumpul dianalisis dengan korelasi dan regresi linier berganda serta uji hipótesis yang dilakukan dengan menggunakan aplikasi program statistik yaitu SPSS 20.0.

Hasil. Hasil penelitian menunjukkan bahwa penelitian terbebas dari asumsi klasik yaitu data berdistribusi normal, dan terbebas dari multikolinearitas, autokorelasi, dan heteroskedastisitas. Secara parsial (sendiri-sendiri) menunjukkan bahwa, ada pengaruh yang signifikan antara Corporate Social Responsibility (CSR) terhadap nilai perusahaan, tidak ada pengaruh yang signifikan antara Kepemilikan Institusional terhadap nilai perusahaan, tidak ada pengaruh yang signifikan antara Kepemilikan Manajerial terhadap nilai perusahaan, profitabilitas berpengaruh signifikan terhadap nilai perusahaan, dan terdapat pengaruh yang signifikan antara struktur modal terhadap nilai perusahaan. Secara simultan ada pengaruh yang signifikan antara Corporate Social Responsibility (CSR), Kepemilikan Institusional, Kepemilikan Manajerial, Profitabilitas, dan Struktur Modal pada perusahaan Manufaktur Barang Konsumsi.

Implikasi. Penelitian selanjutnya bisa menambahkan data penelitian dengan menambah sektor - sektor perusahaan untuk industri lainnya selain perusahaan Manufaktur Sektor Industri Barang Konsumsi, sehingga penelitian ini diharapkan memberikan hasil yang dapat digeneralisasi keseluruhan perusahaan di Indonesia.

Kata Kunci : Corporate Social Responsibility (CSR), Kepemilikan Institusional, Kepemilikan Manajerial, Profitabilitas, Struktur Modal, Nilai Perusahaan

\section{Pendahuluan}

Seiring dengan perkembangan zaman setiap perusahaan saling berkompetisi untuk bisa bertahan dalam dunia industri, inovasi dan pengembangan produk merupakan salah satu upaya yang dilakukan perusahaan untuk terus tumbuh dalam periode waktu yang panjang agar perusahaan tersebut memiliki prospek yang berkelanjutan. Pada dasarnya berdirinya suatu perusahaan adalah untuk memperoleh keuntungan yang maksimal, meningkatkan kesejahteraan pemegang saham, dan memaksimalkan nilai perusahaan yang tercermin pada harga sahamnya. Pengukuran nilai perusahaan sangat penting dilakukan sebagai tolok ukur yang digunakan oleh para investor sebagai bahan pertimbangan untuk menginvestasikan dananya pada suatu perusahaan.

Menurut Irfandi (2015) nilai perusahaan adalah nilai yang mencerminkan berapa harga yang bersedia dibayar oleh investor untuk suatu perusahaan. Nilai perusahaan dapat diukur dengan menggunakan Price Book Value, Tonin's q, bahkan penelitian yang dilakukan oleh Cuong (2012) mengukur nilai perusahaan dengan menggunakan rasio Return on Equity (ROE). Price Book Value merupakan perbandingan antara harga saham dengan nilai buku perusahaan. Dimana nilai buku perusahaan adalah perbandingan antara ekuitas saham biasa dengan jumlah saham yang beredar. Perusahaan dianggap memiliki nilai yang baik apabila perusahaan tersebut memiliki jumlah nilai pasar saham dan nilai pasar hutang yang lebih besar dibandingkan dengan nilai aktivanya.

Berikut disajikan nilai perusahaan yang diukur dengan menggunakan Tobin's $q$ dari 10 (sepuluh) perusahaan manufaktur sektor barang konsumsi. 


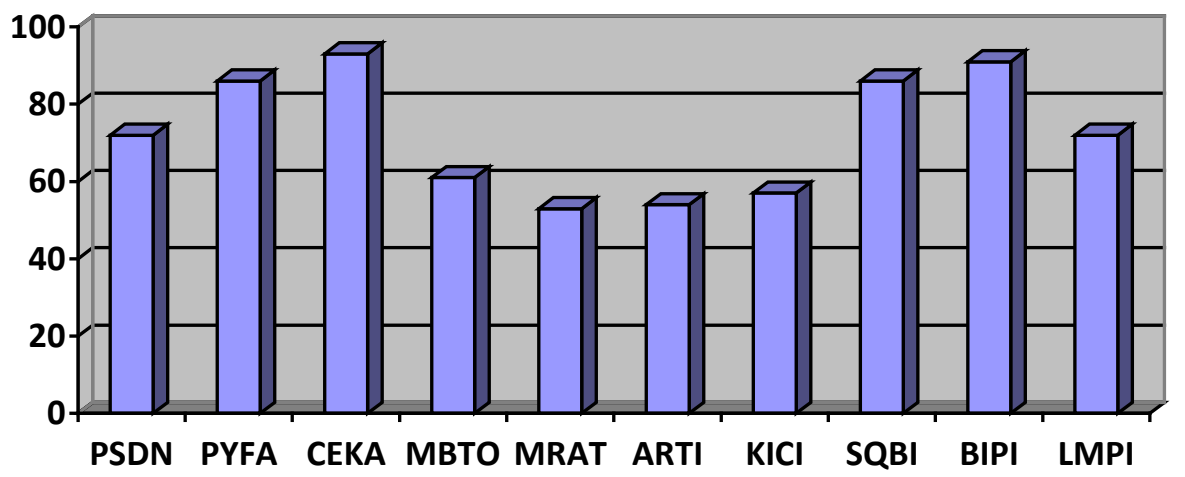

$\square$ Tobins q (\%)

\section{Gambar 1. Grafik Fenomena Nilai Perusahaan (Tobin's $q<100 \%$ ) Tahun 2014}

Dari tabel di atas diperoleh bahwa nilai perusahaan untuk masing-masing perusahaan memiliki angka $<1$ atau $<100 \%$ pada gambar grafik di atas. Semakin rendah angka $q$ maka nilai perusahaan semakin buruk. Tobin's $q<1$ Menggambarkan bahwa saham dalam kondisi undervalued. Hal ini berarti manajemen dianggap telah gagal dalam mengelola aktiva perusahaan yang berakibat pada potensi pertumbuhan investasi rendah. Tobin's $q=1$ menggambarkan bahwa saham dalam kondisi average. Manajemen stagnan dalam mengelola aktiva sehingga potensi pertumbuhan investasi tidak berkembang.

Tobin's $q>1$ menggambarkan bahwa saham dalam kondisi overvalued. Dalam arti manajemen berhasil dalam mengelola aktiva perusahaan sehingga potensi pertumbuhan investasi tinggi. Seperti disajikan dalam grafik di bawah ini:

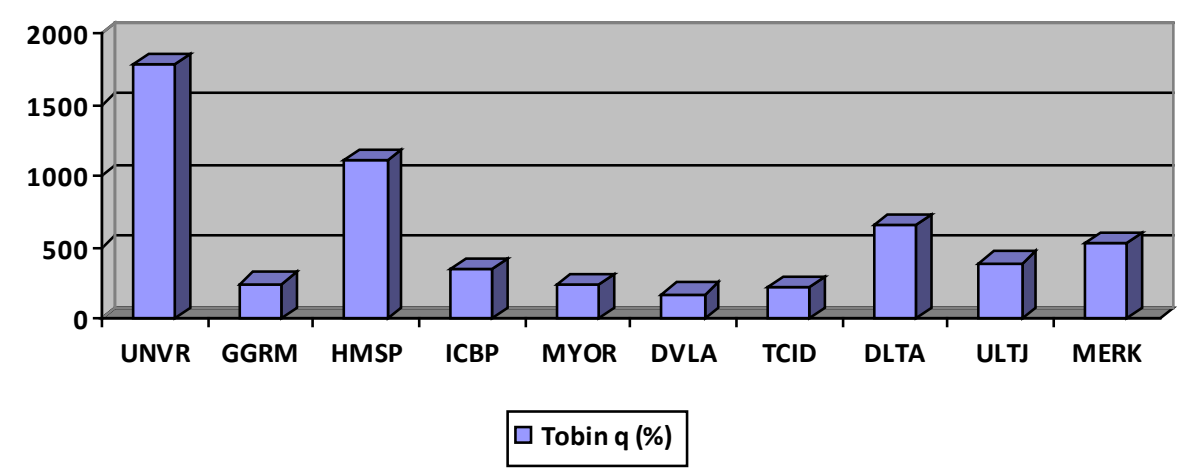

\section{Gambar 2. Grafik Fenomena Nilai Perusahaan (Tobin's $q>$ 100\%) Tahun 2014}

Dari tabel dan grafik fenomena nilai perusahaan di atas dapat dilihat bahwa terdapat 10 perusahaan manufaktur sub sektor barang konsumsi yang memiliki nilai Tobin's $q>1$ dan 6 diantaranya (60\%) dari total perusahaan yang memiliki nilai Tobin's $q<1$ ) adalah perusahaan yang masuk dalam sampel penelitian ini yaitu PT Gudang Garam Tbk (GGRM), PT HM Sampoerna Tbk (HMSP), PT Indofood CBP Sukses Makmur Tbk (ICBP), PT Mandom Indonesia Tbk (TCID), PT Ultra Jaya Milk Industry Tbk (ULTJ), PT Merck Tbk Indonesia (MERK) dan sisanya tidak termasuk karena tidak memenuhi kriteria sampel penelitian. Jadi $30 \%$ dari total sampel perusahaan yang akan diteliti memiliki nilai Tobin's $q>1,30 \%$ memiliki nilai Tobin's $q$ $<1$ dan 40\% sisanya masih belum dilakukan perhitungan. Nilai Tobin's $q$ tertinggi dimiliki oleh PT Unilever Indonesia Tbk (UNVR) karena perusahaan ini memiliki nilai pasar ekuitas yang tinggi yaitu Rp. 246.449.000.000,- dan jumlah aset yang tidak terlalu tinggi yaitu Rp. 14.280.670.000,- jika dibandingkan dengan perusahaan lainnya terutama PT Darya Varia Laboratoria Tbk (DVLA) yang memiliki nilai Tobin's $q$ terendah karena perusahaan ini 
memiliki nilai pasar ekuitas yang rendah yaitu Rp. 1.892.800.000, dan jumlah aset yang rendah juga yaitu Rp. 1.276.248.000,. Selain itu juga produk - produk yang dihasilkan PT Unilever Indonesia Tbk (UNVR) sudah merajai pasar Indonesia dan sudah banyak digunakan oleh masyarakat Indonesia. Sementara PT Darya Varia Laboratoria Tbk (DVLA) masih menempati urutan kelima untuk total aset dan ekuitas yang dimilikinya untuk kategori farmasi.

Berdasarkan hasil penelitian Setyowati dan Nursiam (2014) Corporate Social Responsibility (CSR) berpengaruh positif signifikan terhadap nilai perusahaan, jika CSR perusahaan naik maka akan meningkatkan nilai perusahaan. Semakin banyaknya aktivitas CSR yang diungkapkan oleh perusahaan, maka nilai perusahaan akan semakin meningkat karena pasar akan memberikan apresiasi positif kepada perusahaan yang melakukan CSR yang ditunjukkan dengan peningkatan harga saham perusahaan. Investor mengapresiasi praktik CSR dan melihat aktivitas CSR sebagai pedoman untuk menilai potensi keberlanjutan suatu perusahaan.

Sukirni (2012) menyatakan bahwa kepemilikan institusional berpengaruh positif signifikan terhadap nilai perusahaan. Semakin besar kepemilikan institusional maka semakin efisien pemanfaatan aktiva perusahaan dan diharapkan juga dapat bertindak sebagai pencegahan terhadap pemborosan dan manipulasi laba yang dilakukan oleh manajemen sehingga akan meningkatkan nilai perusahaan.

Hasil penelitian Sukirni (2012) juga menyatakan bahwa kepemilikan manajerial berpengaruh negatif signifikan terhadap nilai perusahaan, hal ini dikarenakan belum banyak pihak manajemen yang memiliki saham perusahaan dengan jumlah yang cukup signifikan, jumlah kepemilikan saham yang belum signifikan tersebut menyebabkan manajer lebih mementingkan tujuannya sebagai seorang manajer daripada sebagai pemegang saham.

Wijaya dan Sedana (2012) menyatakan bahwa profitabilitas berpengaruh signifikan terhadap nilai perusahaan, hal ini disebabkan perusahaan yang mengalami peningkatan laba mencerminkan bahwa perusahaan mempunyai kinerja yang baik, sehingga menimbulkan sentiment positif dari investor dan dapat membuat harga saham perusahaan mengalami peningkatan, meningkatnya harga saham di pasar berarti meningkat pula nilai perusahaan di mata investor.

Trade-off theory menjelaskan bahwa jika posisi struktur modal berada di bawah titik optimal maka setiap penambahan hutang akan meningkatkan nilai perusahaan. Sebaliknya, setiap jika posisi struktur modal berada di atas titik optimal maka setiap penambahan hutang akan menurunkan nilai perusahaan. Oleh karena itu, dengan asumsi titik target struktur modal optimal belum tercapai, maka berdasarkan trade-off theory memprediksi adanya hubungan yang positif terhadap nilai perusahaan (Dewi dan Wirajaya: 2013).

Berdasarkan beberapa permaslahan diatas penulis ingin menelitih lebih lanjut terkait

Pengaruh Corporate Social Responsibility (CSR), Kepemilikan Institusional, Kepemilikan Manajerial, Profitabilitas dan Struktur Modal Terhadap Nilai Perusahaan (Studi Empiris Pada Perusahaan Manufaktur Sektor Industri Barang Konsumsi Yang Terdaftar di Bursa Efek Indonesia Periode Tahun 2011-2015).

\section{Kajian Pustaka dan Hipotesis}

Corporate Social Responsibility (CSR). Menurut Cheng dalam Rosiana dkk (2013), aktivitas CSR dapat memberikan banyak manfaat, seperti: dapat meningkatkan citra dan daya tarik perusahaan di mata investor serta analis keuangan penjualan, dapat menunjukan brand positioning, dan dapat meningkatkan penjualan dan market share. Pengungkapan CSR merupakan proses pemberian informasi kepada kelompok yang berkepentingan tentang aktivitas perusahaan serta dampaknya terhadap sosial dan lingkungan (Rosiana dkk, 2013).

Kepemilikan Institusional. Kepemilikan institusional adalah kepemilikan saham perusahaan yang dimiliki oleh institusi atau lembaga seperti: perusahaan asuransi, bank, perusahaan investasi dan kepemilikan institusi lain" (Sukirni, 2012:4). "Kepemilikan institusional merupakan komposisi persentase kepemilikan saham yang dimiliki oleh institusi" (Sugiarto, 2009:18). 
Kepemilikan Manajerial. "Kepemilikan manajerial merupakan porsi kepemilikan saham yang dimiliki oleh orang dalam (insider)" (Sugiarto, 2009:59). "Tingkat konsentrasi dan komposisi kepemilikan menentukan distribusi kekuasaan perusahaan antara manajer dan pemegang saham, yang pada dirinya akan mempengaruhi sifat pengambilann keputusan yang berpengaruh pada perkembangan perusahaan" (Sutedi, 2012: 9).

Profitabilitas. "Rasio profitabilitas merupakan rasio untuk menilai kemampuan perusahaan dalam mencari keuntungan. Rasio ini juga memberikan ukuran tingkat efektivitas manajemen suatu perusahaan. Hal ini ditunjukkan oleh laba yang dihasilkan dari penjualan dan pendapatan investasi, selain itu juga penggunaan rasio ini menunjukkan efisiensi perusahaan" (Kasmir, 2014:196). "Profitabilitas mencerminkan hasil akhir dari seluruh kebijakan keuangan dan keputusan operasional” (Brigham dan Houston, 2010:146).

Struktur Modal. "Struktur modal adalah kombinasi utang dan modal sendiri yang akan menjadi dasar penghimpunan modal oleh perusahaan" (Brigham dan Houston, 2011). "Struktur modal merupakan pendanaan ekuitas dan utang pada suatu perusahaan yang sering dihitung berdasarkan besaran relatif berbagai sumber pendanaan" (Subramanyam, 2010:263).

Nilai Perusahaan. Nilai perusahaan adalah nilai pasar hutang ditambah dengan nilai pasar ekuitas, hutang merupakan sebuah janji dari perusahaan peminjam untuk membayar kembali sejumlah uang pada tanggal tertentu. Klaim hak pemegang saham terhadap nilai perusahaan merupakan nilai sisa (residual) setelah hak pemegang surat hutang dibayarkan, (Rodoni, 2010:4). Nilai perusahaan merupakan harga yang bersedia dibayar oleh calon pembeli apabila perusahaan tersebut dijual" (Husnan, 2015: 6).

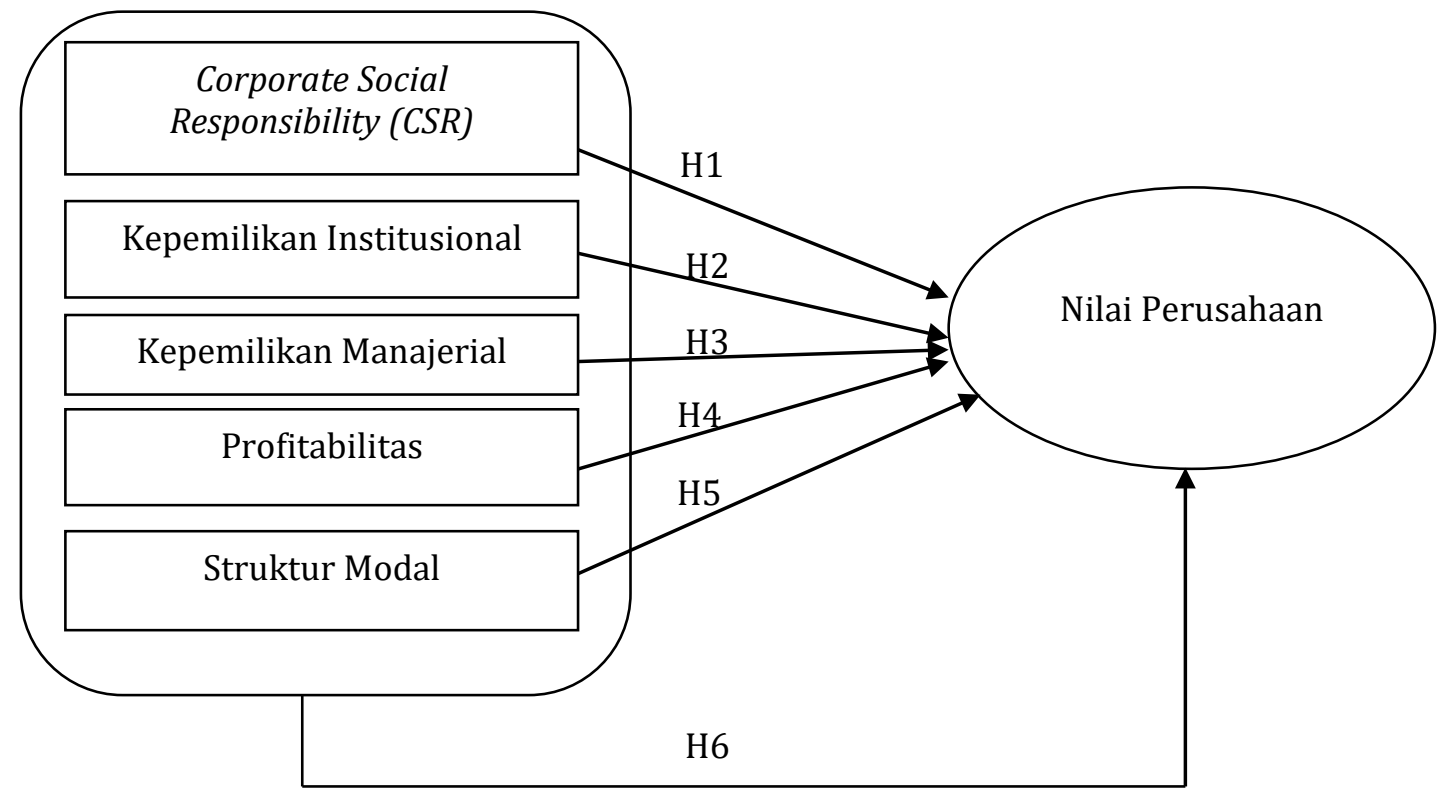

Gambar 3. Model Penelitian

\section{Hipotesis}

H1 : Corporate Social Responsibility (CSR) berpengaruh signifikan terhadap nilai perusahaan

H2 : Kepemilikan institusional berpengaruh signifikan terhadap nilai perusahaan

H3 : Kepemilikan manajerial berpengaruh signifikan terhadap nilai perusahaan

H4 : Profitabilitas berpengaruh signifikan terhadap nilai perusahaan

H5 : Struktur modal berpengaruh signifikan terhadap nilai perusahaan

H6 : Corporate social responsibility (CSR), kepemilikan institusional, kepemilikan manajerial, profitabilitas dan struktur modal secara bersama-sama mempengaruhi nilai perusahaan 


\section{Metode Penelitian}

Jenis penelitian ini adalah deskriptif kuantitatif, yaitu melakukan pembahasan atas permasalahan yang dihadapi perusahaan terhadap kinerja perusahaan dari segi keuangan, data-data analisa yang digunakan adalah data yang bersifat kuantitatif yaitu data-data yang bersifat angka-angka. Dalam penelitian populasinya adalah seluruh perusahaan manufaktur sektor industri barang konsumsi yang terdaftar di Bursa Efek Indonesia selama tahun 20112015. Teknik pengambilan sampel yang digunakan adalah Non Probability Sampling yaitu purposive sampling. Jumlah perusahaan yang digunakan sebagai sampel sebanyak 8 perusahaan pada periode $2011-2015$.

\section{Analisis Deskriptif}

Menurut Sugiyono (2015:147) "Analisis deskriptif digunakan untuk menganilisis data dengan cara mendeskripsikan atau mengambar data yang terkumpul". Statistik deskriptif memberikan gambaran atau data yang dilihat dari rata-rata (mean), standar deviasi, varian, maksimum, minimum, sum, range, kurtosis dan Skewness (kemencangan distribusi).

\section{Uji Asumsi Klasik}

Uji asumsi klasik digunakan untuk mengetahui ketepatan sebuah data. Menurut Santoso (2015:342) berpendapat "Sebuah model regresi akan digunakan untuk melakukan peramalan sebuah model yang baik adalah model dengan kesalahan peramalan yang seminimal mungkin. Karena itu, sebuah model sebelum digunakan seharusnya memenuhi beberapa asumsi, yang biasa disebut asumsi klasik". Dalam penelitian ini uji asumsi klasik yang digunakan: Uji Normalitas, Uji Multikolinearitas, Uji Autokorelasi, dan Uji Heterokedastisitas.

\section{Analisis Kuantitatif}

Analisis kuantitatif adalah penelitian untuk menilai kondisi dari nilai pengaruh, dan signifikansi pengaruh tersebut. Dalam penelitian ini analisis kuantitatif yang digunakan: Analisis Regresi Berganda, Uji Parsial (Uji-t), Uji-F, dan Koefisien Determinasi.

\section{Hasil Penelitian dan Pembahasan Statistik Deskriptif}

Tabel 1 Statistik Deskriptif

\begin{tabular}{lrrrrr}
\hline & N & Minimum & Maximum & \multicolumn{1}{c}{ Mean } & \multicolumn{1}{c}{ Std. Deviation } \\
\hline TOBINS_Q & 40 & 54.86 & 711.38 .00 & 2.363 .983 & 16.397 .691 \\
CSR & 40 & 06.33 & 51.90 & 243.043 & 1.518 .507 \\
KI & 40 & 44.52 .00 & 95.06 .00 & 666.617 & 1.613 .186 \\
KM & 40 & .00 & 23.08 & 53.913 & 895.883 \\
ROE & 40 & -13.92 & 24.08 .00 & 129.343 & 735.500 \\
DER & 40 & 25.22 .00 & 112.96 & 540.310 & 2.274 .986 \\
Valid N (listwise) & 40 & & & & \\
\hline
\end{tabular}

Sumber: Data diolah

Dari tabel di atas diketahui nilai Tobins'q terendah adalah 54.86 dan tertinggi adalah 711.38 dengan rata-rata 236.3983 dan standar deviasi 163.97691. Untuk variabel corporate social responsibility (CSR) nilai terendah adalah 6.33 dan yang tertinggi adalah 51.90 dengan rata-rata 24.3043 dan standar deviasi 15.18507. Untuk variabel kepemilikan institusional nilai terendah adalah 44.52 dan yang tertinggi adalah 95.06 dengan rata-rata 66.6617 dan standar deviasi 16.13186. Untuk variabel kepemilikan manajerial nilai terendah adalah 0.00 dan yang tertinggi adalah 23.08 dengan rata-rata 5.3913 dan standar deviasi 8.95883. Untuk variabel profitabilitas yang diproksikan dengan return on equity nilai terendahnya adalah -13.92 dan yang tertinggi adalah 24.08 dengan rata-rata 12.9343 dan standar deviasi 7.35500. Dan untuk varibael struktur modal yang diproksikan oleh debt to equity nilai terendahnya adalah 25.22 dan yang tertinggi adalah 112.96 dengan rata-rata 54.0310 dan standar deviasi 22.74986. 


\section{Asumsi Klasik}

Uji Normalitas

Tabel 2. Hasil Uji Normalitas

\begin{tabular}{|c|c|c|}
\hline & & Unstandardized Residual \\
\hline $\mathrm{N}$ & & 40 \\
\hline \multirow{3}{*}{ Normal Parameters ${ }^{\mathrm{a}, \mathrm{b}}$} & Mean & $0,00 \mathrm{E}+00$ \\
\hline & Std. Deviation & 8.509.491.744 \\
\hline & Absolute & .060 \\
\hline \multirow[t]{2}{*}{ Most Extreme Differences } & Positive & .060 \\
\hline & Negative & -.051 \\
\hline Kolmogorov-Smirnov Z & & .380 \\
\hline Asymp. Sig. (2-tailed) & & .999 \\
\hline
\end{tabular}

a. Test distribution is Normal.

b. Calculated from data.

Sumber: Data diolah

Dari tabel hasil pengolahan data diperoleh bahwa data dalam penelitian ini terdistribusi secara normal dimana nilai signifikasi (Asymp. Sig. (2-tiled)) sebesar 0,999 lebih besar dari $0,05(0,999>0,05)$. Dengan demikian secara keseluruhan dapat disimpulkan bahwa data telah terdistribusi normal dan dapat dilanjutkan dengan uji asumsi klasik lainnya.

Uji Multikolinearitas

Tabel 3. Hasil Uji Multikolinearitas

\begin{tabular}{ccc}
\hline \multirow{2}{*}{ Model } & \multicolumn{2}{c}{ Collinearity Statistics } \\
& Tolerance & VIF \\
\hline CSR & .417 & 2.398 \\
KI & .411 & 2.434 \\
KM & .398 & 2.511 \\
ROE & .574 & 1.742 \\
DER & .812 & 1.232 \\
\hline
\end{tabular}

a. Dependent Variable: TOBINS_Q

Sumber: Data diolah

Dari hasil di atas dapat diketahui nilai Variance Inflation Factor (VIF) masing - masing variabel yaitu corporate social responsibility (CSR) adalah 2.398, kepemilikan institusional (KI) adalah 2.434 , kepemilikan manajerial adalah 2.511 , return on equity (ROE) adalah 1.742 , dan debt to equity (DER) adalah 1.232 kelimanya lebih kecil dari 10, dan nilai tolerance kelima variabel tidak kurang dari 0.1 . Sehingga dapat disimpulkan bahwa antar variabel independen tidak terjadi persoalan multikolinearitas.

\section{Uji Heteroskedastisitas}

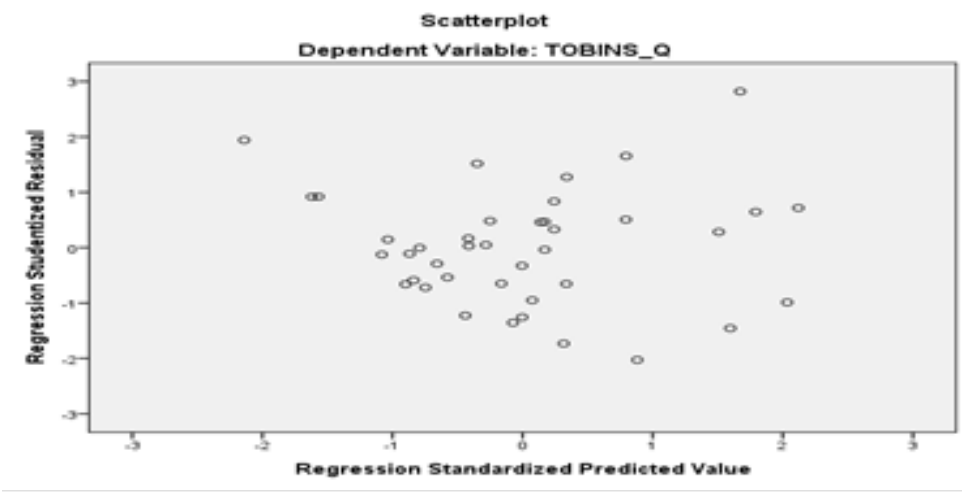

Gambar 4. Hasil Uji Heteroskedastisitas 
Dari grafik scatterplot di atas terlihat bahwa titik-titik menyebar secara acak, tidak membentuk sebuah pola tertentu yang jelas, serta tersebar baik diatas maupun dibawah angka 0 pada sumbu Y, maka dapat disimpulkan bahwa tidak terjadi heteroskedastisitas pada model regresi ini, sehingga model regresi layak digunakan.

\section{Uji Autokorelasi}

Tabel 4 Hasil Uji Autokorelasi

\begin{tabular}{cccccc}
\hline Model & $\mathrm{R}$ & $\mathrm{R}$ Square & $\begin{array}{c}\text { Adjusted R } \\
\text { Square }\end{array}$ & $\begin{array}{c}\text { Std. Error of the } \\
\text { Estimate }\end{array}$ & $\begin{array}{c}\text { Durbin- } \\
\text { Watson }\end{array}$ \\
\hline 1 & $.855^{\mathrm{a}}$ & .731 & .691 & 9.113 .736 & 1.794 \\
\hline
\end{tabular}

a. Predictors: (Constant), DER, KM, CSR, ROE, KI

b. Dependent Variable: TOBINS_Q

Sumber : Data diolah (2021)

Dari tabel 4.10 di atas diketahui bahwa angka DW adalah sebesar 1,794. Dilihat dari tabel Durbin Watson untuk variabel independen $(\mathrm{k})=5$ dan jumlah sample data $(\mathrm{n})=40$ dengan tingkat signifikasi 0,05 diperoleh dL adalah 1,231 dan dU adalah 1,786. Sedangkan untuk 4-dU didapatkan nilai 2,214 dan 4-dL sebanyak 2,769. Sehingga angka DW yang dihasilkan berada pada $\mathrm{dU}<\mathrm{d}<4-\mathrm{dU}$ yaitu 1,786 $<1,794<2,214$ yang berarti tidak ada autokorelasi positif ataupun negatif.

\section{Regresi Linier Berganda}

Tabel 5 Hasil Uji Regresi Linier Berganda

\begin{tabular}{llccccc}
\hline Model & \multicolumn{2}{c}{ Unstandardized Coefficients } & $\begin{array}{c}\text { Standardized } \\
\text { Coefficients } \\
\text { Beta }\end{array}$ & T & Sig. \\
\hline \multirow{2}{*}{ (Constant) } & B & Std. Error & & & \\
\hline & CSR & 3.042 .104 & 139.200 & & 2.170 & .037 \\
1 KI & -1.251 & 1.488 & .282 & 2.044 & .049 \\
KM & -.717 & 1.411 & -.123 & -.886 & .382 \\
& ROE & 9.832 & 2.582 & -.039 & -.278 & .783 \\
DER & -3.323 & 2.619 & .441 & 3.754 & .001 \\
\hline
\end{tabular}

a. Dependent Variable: TOBINS_Q

Sumber : Data diolah

$Y=302,104+3,042 X_{1}-1,251 X_{2}-0,717 X_{3}+9,832 X_{4}-3,323 X_{5}$

1) Konstanta sebesar 302,104; artinya jika variabel independent corporate social responsibility (CSR) (X1), kepemilikan institusional (X2), kepemilikan manajerial (X3), profitabilitas (X4) dengan proksi return on equity (ROE), dan struktur modal (X5) dengan proksi debt to equity (DER) nilainya adalah 0 , maka nilai perusahaan $(\mathrm{Y})$ nilainya adalah 302,104.

2) Koefisien regresi variabel corporate social responsibility (CSR) (X1) sebesar 3,042; artinya jika variabel independent lain nilainya tetap dan corporate social responsibility (CSR) mengalami kenaikan 1\%, maka nilai perusahaan (Y) akan mengalami kenaikan sebesar 3,042 .

3) Koefisien regresi variabel kepemilikan institusional (X2) sebesar -1,251; artinya jika variabel independent lain nilainya tetap dan kepemilikan institusional mengalami kenaikan $1 \%$, maka nilai perusahaan $(\mathrm{Y})$ akan mengalami penurunan sebesar 1,251.

4) Koefisien regresi variabel kepemilikan manajerial (X3) sebesar -0,717; artinya jika variabel independent lain nilainya tetap dan kepemilikan manajerial mengalami kenaikan 1\%, maka nilai perusahaan (Y) akan mengalami penurunan sebesar 0,717.

5) Koefisien regresi variabel profitabilitas dengan proksi return on equity (ROE) (X4) sebesar 9,832; artinya jika variabel independent lain nilainya tetap dan return on equity (ROE) mengalami kenaikan 1\%, maka nilai perusahaan (Y) akan mengalami kenaikan sebesar 9,832 . 
6) Koefisien regresi variabel struktur modal dengan proksi debt to equity (DER) (X5) sebesar 3,323; artinya jika variabel independent lain nilainya tetap dan debt to equity (DER) mengalami kenaikan 1\%, maka nilai perusahaan $(\mathrm{Y})$ akan mengalami penurunan sebesar 3,323 .

\section{Pengujian Hipotesis}

Tabel 6. Hasil Uji Hipotesis Parsial

\begin{tabular}{ccc}
\hline Model & $\mathrm{T}$ & Sig. \\
\hline CSR & 2.044 & .049 \\
KI & -.886 & .382 \\
KM & -.278 & .783 \\
ROE & 3.754 & .001 \\
DER & -4.668 & .000 \\
\hline
\end{tabular}

a. Dependent Variable: TOBINS_Q

Sumber : Data diolah

1) Variabel CSR memiliki nilai $t_{\text {hitung }}(2,044)>t_{\text {tabel }}(2.032)$ dengan sig $(0.049<0.05)$, maka Ho ditolak atau H1 diterima, sehingga dari hasil tersebut dapat disimpulkan bahwa secara parsial (sendiri-sendiri) ada pengaruh yang signifikan antara Corporate Social Responsibility (CSR) terhadap nilai perusahaan.

2) Variabel Kepemilikan institusional memiliki nilai $t_{\text {hitung }}(-0,886)>t_{\text {tabel }}(-2.032)$ dengan sig $(0.382>0.05)$, maka Ho diterima atau H1 ditolak, sehingga dari hasil tersebut dapat disimpulkan bahwa secara parsial (sendiri-sendiri) tidak ada pengaruh yang signifikan antara Kepemilikan institusional terhadap nilai perusahaan.

3) Variabel Kepemilikan Manajerial $t_{\text {hitung }}$ dan $t_{\text {tabel }}$ ternyata $t_{\text {hitung }}(-0,278)>t_{\text {tabel }}(-2.032)$ atau mengunakan probabilitas value juga dapat dilihat bahwa probabilitas value (signifikansi) sebesar 0.783 lebih besar dari $0.05(0.783>0.05)$, maka Ho diterima atau H1 ditolak, sehingga dari hasil tersebut dapat disimpulkan bahwa secara parsial (sendiri-sendiri) tidak ada pengaruh yang signifikan antara Kepemilikan Manajerial terhadap nilai perusahaan.

4) Variabel ROE memiliki nilai $t_{\text {hitung }}(3,754)>t_{\text {tabel }}(2.032)$ dengan sig $(0.001<0.05)$, maka Ho ditolak atau $\mathrm{H} 1$ diterima, sehingga dari hasil tersebut dapat disimpulkan bahwa secara parsial (sendiri-sendiri) ada pengaruh yang signifikan antara Return on Equity (ROE) terhadap nilai perusahaan.

5) Variabel DER memiliki nilai $t_{\text {hitung }}(-4,668)<t_{\text {tabel }}(-2.032)$ dengan sig $(0.000<0.05)$, maka Ho ditolak atau H1 diterima, sehingga dari hasil tersebut dapat disimpulkan bahwa secara parsial (sendiri-sendiri) ada pengaruh yang signifikan antara Debt to Equity (DER) terhadap nilai perusahaan.

Tabel 7. Hasil Pengujian Hipotesis Simultan

\begin{tabular}{ccccccc}
\hline & Model & Sum of Squares & Df & Mean Square & F & Sig. \\
\hline \multirow{4}{*}{1} & Regression & 766.243 .968 & 5 & 153.248 .794 & 18.450 & $.000^{\mathrm{b}}$ \\
& Residual & 282.404 .654 & 34 & 8.306 .019 & & \\
& Total & 1.048 .648 .622 & 39 & & & \\
\hline
\end{tabular}

a. Dependent Variable: TOBINS_Q

b. Predictors: (Constant), DER, KM, CSR, ROE, KI

Sumber : Data diolah

Dari tabel 7 di atas dapat dilihat bahwa nilai sig. 0,000 $<0,05$ yang berarti signifikan dan didukung oleh hasil uji $\mathrm{F}$ yaitu $\mathrm{F}$ hitung 18,450 > F tabel 2,49 sehingga $\mathrm{H}_{\mathrm{o}}$ ditolak dan $\mathrm{H}_{\mathrm{a}}$ diterima. Jadi dapat disimpulkan bahwa Corporate social responsibility (CSR), kepemilikan institusional, kepemilikan manajerial, profitabilitas dan struktur modal secara bersama-sama (simultan) mempengaruhi nilai perusahaan. 
Tabel 8. Hasil Uji Koefisien Determinasi

\begin{tabular}{cccccc}
\hline Model & $\mathrm{R}$ & R Square & $\begin{array}{c}\text { Adjusted R } \\
\text { Square }\end{array}$ & $\begin{array}{c}\text { Std. Error of the } \\
\text { Estimate }\end{array}$ & $\begin{array}{c}\text { Durbin- } \\
\text { Watson }\end{array}$ \\
\hline 1 & $.855^{\mathrm{a}}$ & .731 & .691 & 9.113 .736 & 1.794 \\
\hline
\end{tabular}

a. Predictors: (Constant), DER, KM, CSR, ROE, KI

b. Dependent Variable: TOBINS_Q

Sumber : Data diolah

Jumlah variabel independen yang digunakan dalam penelitian lebih dari 2 maka koefisien determinasi yang digunakan dalam penelitian ini adalah nilai dari Adjusted $R$ Square, karena nilai ini benar - benar mencerminkan besarnya kontribusi variabel independen dalam menjelaskan variabel dependen (Nilai Perusahaan). Dalam tabel tersebut dapat dilihat bahwa nilai dari Adjusted $R$ Square $=0,691$ atau sebesar 69,1\%. Hal ini menunjukkan bahwa persentase sumbangan pengaruh variabel Corporate social responsibility (CSR), kepemilikan institusional, kepemilikan manajerial, profitabilitas dan struktur modal terhadap nilai perusahaan sebesar $69,1 \%$, sedangkan sisanya sebesar 30,9\% dipengaruhi oleh variabel lain yang tidak termasuk dalam model penelitian ini.

\section{Pembahasan Penelitian}

Berdasarkan pengujian hipotesis pada sub bab sebelumnya, variabel corporate social responsibility (CSR) berpengaruh signifikan terhadap nilai perusahaan dengan koefisien regresi bernilai positif. Hal ini menunjukkan bahwa semakin banyak suatu perusahaan mengungkapkan corporate social responsibility (CSR) maka nilai perusahaannya pun akan semakin baik dan semakin sedikit suatu perusahaan mengungkapkan corporate social responsibility (CSR) maka nilai perusahaannya akan semakin buruk di mata para investor. Sehingga H1: "corporate social responsibility (CSR) berpengaruh terhadap nilai perusahaan" dapat diterima. Berdasarkan pengujian hipotesis pada sub bab sebelumnya, secara parsial variabel kepemilikan institusional tidak berpengaruh signifikan terhadap nilai perusahaan yang dibuktikan dengan nilai signifikansi yang hasilnya lebih dari 0,05. Sehingga H2: "kepemilikan institusional berpengaruh terhadap nilai perusahaan" ditolak.

Berdasarkan pengujian hipotesis pada sub bab sebelumnya, secara parsial variabel kepemilikan manajerial tidak berpengaruh signifikan terhadap nilai perusahaan yang dibuktikan dengan nilai signifikansi yang hasilnya lebih dari 0,05. Sehingga H3: "kepemilikan manajerial berpengaruh terhadap nilai perusahaan" ditolak. Berdasarkan pengujian hipotesis pada sub bab sebelumnya, variabel profitabilitas dengan proksi return on equity (ROE) berpengaruh signifikan terhadap nilai perusahaan dengan koefisien regresi bernilai positif, hal ini menunjukkan bahwa semakin tinggi nilai return on equity (ROE) maka nilai perusahaannya pun akan semakin tinggi dan semakin rendah return on equity (ROE) maka nilai perusahaannya akan semakin rendah pula. Sehingga H4: "return on equity (ROE) berpengaruh terhadap nilai perusahaan" dapat diterima.

Berdasarkan pengujian hipotesis pada sub bab sebelumnya, variabel struktur modal dengan proksi debt to equity (DER) berpengaruh signifikan terhadap nilai perusahaan dengan koefisien regresi bernilai negatif, hal ini menunjukkan bahwa semakin tinggi nilai debt to equity (DER) maka nilai perusahaannya akan semakin rendah dan semakin rendah debt to equity (DER) maka nilai perusahaannya pun akan semakin tinggi. Sehingga H5: "debt to equity (DER) berpengaruh terhadap nilai perusahaan" dapat diterima.

\section{Kesimpulan}

Corporate Social Responsibility (CSR) berpengaruh signifikan terhadap Nilai Perusahaan hal ini karena semakin banyak kegiatan tanggung jawab sosial perusahaan yang dilakukan akan menjadi sinyal positif bagi para pemangku kepentingan yang menimbulkan rasa percaya terhadap perusahaan yang membuat citra perusahaan baik dimata publik dan akan meningkatkan nilai perusahaan. Kepemilikan Institusional tidak berpengaruh signifikan terhadap Nilai Perusahaan hal ini karena pemegang saham institusional hanyalah sebagai 
pengawas kinerja perusahaan, seluruh kegiatan operasional dijalankan oleh manajer perusahaan yang nantinya akan mempertanggungjawabkan hasil kinerjanya kepada para pemegang saham sehingga ada atau tidaknya kepemilikan institusional tidak berpengaruh pada nilai perusahaan. Kepemilikan Manajerial tidak berpengaruh signifikan terhadap Nilai Perusahaan hal ini karena rendahnya kepemilikan manajerial dalam perusahaan dimungkinkan hanya sebagai investasi semata atau sebagai bentuk kontribusi dari pihak manajerial terhadap perusahaan sehingga besar atau kecilnya kepemilikan ini tidak akan mempengaruhi nilai perusahaan.

Profitabilitas dengan proksi Return on Equity (ROE) berpengaruh signifikan terhadap Nilai Perusahaan hal ini karena Return on equity (ROE) digunakan sebagai sinyal positif untuk menarik investor, semakin besar nilainya maka sinyal yang diberikan pun semakin baik sehingga semakin banyak investor yang akan menginvestasikan dananya pada perusahaan yang akan meningkatkan harga saham perusahaan dan tentu saja akan berdampak langsung pada nilai perusahaan. Struktur Modal dengan proksi Debt to Equity (DER) berpengaruh signifikan terhadap Nilai Perusahaan hal ini karena sesuai dengan trade off theory yang menyatakan bahwa hutang bisa menambah nilai perusahaan hanya pada batas tertentu, ketika sudah melebihi batas tersebut yaitu kondisi dimana hutang yang dimiliki perusahaan semakin besar maka kewajiban yang harus dibayarpun akan semakin besar pula, ketika kewajiban yang ditimbulkan hutang tersebut jauh lebih besar daripada manfaat hutang itu sendiri pada saat itulah hutang bisa menurunkan nilai perusahaan. Corporate Social Responsibility (CSR), Kepemilikan Institusional, Kepemilikan Manajerial, Profitabilitas dengan proksi Return on Equity (ROE), dan Struktur Modal dengan proksi Debt to Equity (DER) secara bersama-sama (simultan) berpengaruh signifikan terhadap Nilai Perusahaan.

\section{Daftar Pustaka}

Adnantara, Komang Fridagustina. 2013. Pengaruh Struktur Kepemilikan Saham dan Corporate Social Responsibility pada Nilai Perusahaan. Jurnal Buletin Studi Ekonomi Vol. 18 No. 2, $107-113$.

Alfaraih, Mishari, Faisal Alanezi \& Hesham Almujamed. 2012. The Influence Of Institutional and Government Ownership on Firm Performance: Evidence From Kuwait. International Business Research Vol. 5 No. 10, 192 - 200.

Brigham, Eugene, F dan Joel F, Houston 2010. Dasar-dasar Manajemen Keuangan, Buku 1, Edisi Sebelas. Jakarta: Salemba Empat.

Brigham, Eugene, F dan Joel F, Houston 2011. Dasar-dasar Manajemen Keuangan, Buku 2, Edisi Sebelas. Jakarta: Salemba Empat.

Cuong, Nguyen Thanh. dan Nguyen Thi Canh. 2012. The Effect of Capital Structure on Firm Value for Vietnam's Seafood Processing Enterprisess. International Research Journal of Finance and Economics Issue 89, 221 - 233.

Dewi, Ayu S. M., dan Ary Wijaya. 2013. Pengaruh Struktur Modal, Profitabilitas, dan Ukuran Perusahaan pada Nilai Perusahaan. E-Jurnal Akuntansi Universitas Udayana Vol. 4 No. 2, 358-371.

Dewi, I. K., dan Solihin, D. (2020). Pengaruh Current Ratio Dan Net Profit Margin Terhadap Harga Saham Pada Perusahaan Makanan Dan Minuman Yang Terdaftar Di Bursa Efek Indonesia (BEI) Periode 2015-2018. JURNAL ILMIAH FEASIBLE: Bisnis, Kewirausahaan \& Koperasi 2 (2), 183-191.

Gudono. 2015. Analisis Data Multivariat. Edisi 4. Yogyakarta: BPFE.

Ghozali, Imam. 2011. Ekonometrika Teori, Konsep dan Aplikasi dengan SPSS 17. Semarang: Badan Penerbit Universitas Diponegoro.

Hakim, Abdul. 2010. Statistik Deskriptif Untuk Ekonomi \& Bisnis. Yogyakarta: EKONISIA. 
Husnan, Suad, dan Enny, Pudjiastuti. 2015. Dasar-Dasar Manajemen Keuangan. Yogyakarta: UPP STIM YKPN.

Indriantoro, Nur, dan Bambang, Supomo. 2014. Metodologi Penelitian Bisnis Untuk Akuntansi \& Manajemen. Yogyakarta. BPFE.

Kasmir. 2014. Analisis Laporan Keuangan. Jakarta: Raja Grafindo Persada.

Keown, Arthur J., et al. 2010. Dasar-Dasar Manajemen. Buku 2. Edisi Pertama. Jakarta: Salemba Empat.

Mardikanto, Totok. 2014. Corporate Social Responsibility (Tanggungjawab Sosial Korporasi). Bandung: Alfabeta.

Nahda, Katiya. dan D. Agus Harjito. 2011. Pengaruh Corporate Social Responsibility Terhadap Nilai Perusahaan Dengan Corporate Governance Sebagai Variabel Moderasi. Jurnal siasat Bisnis Vol. 15 No. 1,1 - 12.

Nidar, Sulaeman, Rahman. 2016. Manajemen Keuangan Perusahaan Modern. Bandung: Pustaka Reka Cipta.

Prihadi, Toto. 2010. Analisis Laporan Keuangan Teori dan Aplikasi. Jakarta : PPM.

Prihadi, Toto. 2013. Analisis Laporan Keuangan Lanjutan Proyeksi dan Valuasi. Jakarta: PPM.

Priyatno, Duwi 2012. Cara Kilat Belajar Analisis Data dengan SPSS 20. Yogyakarta: Andi Offset.

Rodoni, Ahmad, dan Herni, Ali. 2010. Manajemen Keuangan Edisi Pertama. Jakarta: Mitra Wacana Media.

Rosiana, Gusti Ayu Made E., Gede Juliarsa, dan Maria M. Ratna Sari. 2013. Pengaruh Pengungkapan CSR Terhadap Nilai Perusahaan Dengan Profitabilitas sebagai Variabrl Pemoderasi. E-Jurnal Akuntansi Universitas Udayana Vol. 5 No. 3, 723 - 738.

Rusdianto, Ujang. 2013. CSR Communications A Framework for PR Practitioners. Yogyakarta: Graha Ilmu.

Santoso, Singgih. 2012. Analisis SPSS pada Statistik Parametrik. Jakarta: PT. Elex Media Computindo.

Sarjono, Haryadi, dan Winda, Julianita. 2011. SPSS vs Lisrel Sebuah Pengantar Aplikasi Untuk Riset. Jakarta: Salemba Empat.

Servaes, Henri. dan Ane Tamayo. 2013. The Impact of Corporate Social Responsibility on Firm Value: The Role of Customer Awareness. Management Science Vol. 59 No. 5, 1045 - 1061.

Setyowati, Tatik. dan Nursiam. 2014. Pengaruh Profitabilitas, Kebijakan Dividen, dan Corporate Social Responsibility (CSR) Terhadap Nilai Perusahaan (Studi Empiris pada Perusahaan Manufaktur yang Listing di BEI Tahun 2009-2012). Seminar Nasional dan Call for Paper Program Studi Akuntansi-Feb UMS, 387 - 400.

Sjahrial, Dermawan. 2007. Pengantar Manajemen Keuangan. Edisi Kedua. Jakarta: Mitra Wacana Media.

Solihin, D. (2019), Pengaruh Current Ratio dan Debt To Equity Ratio Terhadap Return On Asset (ROA) Pada PT Kalbe Farma, Tbk. KREATIF: Jurnal Ilmiah Prodi Manajemen Universitas Pamulang 7 (1), 115-122.

Subramanyam, K. R. dan John J. Wild. 2010. Analisis Laporan Keuangan Buku 1 dan 2. Jakarta: Salemba Empat.

Sugiarto. 2009. Struktru Modal, Struktur Kepemilikan Perusahaan, Permasalahan Keagenan \& Informasi Asimetri. Yogyakarta: Graha Ilmu.

Sugiono. 2012. Metode Penelitian Kuantitatif Kualitatif dan R\&D. Bandung : Alfabeta. 
Sugiono, Arief, dan Edi Untung. 2016. Panduan Praktis Dasar Analisa Laporan Keuangan. Jakarta: Grasindo.

Sugiyono. 2010. Metode Penelitian Bisnis. Cetakan ke-14. Bandung: Alfabeta.

Suhartati, Titi, Sabar Warsini, dan Nedsal Sixpria. 2011. Pengaruh Pengungkapan Tanggung Jawab Sosial dan Praktik Tata Kelola Perusahaan Terhadap Nilai Perusahaan. Jurnal Ekonomi dan Bisnis Vol. 10 No. 2, 95 - 105.

Sukirni, Dwi. 2012. Kepemilikan Manajerial, Kepemilikan Institusional, Kebijakan Deviden dan Kebijakan Hutang Analisis Terhadap Nilai Perusahaan. Accouning Analysis Journal Vol. 1 No. 2, $1-12$.

Sunyoto, Danang. 2011. Analisis Regresi dan Uji Hipotesis. Yogyakarta : Caps.

Sutedi, Adrian. 2012. Good Corporate Governance. Jakarta: Sinar Grafika.

Suyanto, Bagong, dan Sutinah. 2011. Metode Penelitian Sosial, Berbagai Alternatif Pendekatan, Edisi revisi. Jakarta : Prenada Media.

Wijaya, Bayu I., dan I.B. Panji Serdana. 2015. Pengaruh Profitabilitas Terhadap Nilai Perusahaan (Kebijakan Dividend dan Kesempatan Investasi sebagai Variabel Mediasi). EJurnal Manajemen Unud. Vol. 4 No. 12, 4477 - 4500.

Wulandari, Dwi Retno. 2013. Pengaruh Profitabilitas, Opertaing Leverage, Likuiditas Terhadap Nilai Perusahaan Dengan Struktur Modal Sebagai Intervening. Accouning Analysis Journal Vol. 3 No. 1, 455 - 463.

Tampubolon, Manahan, P. 2013. Manajemen Keuangan (Finance Management). Jakarta: Mitra Wacana Media. 